\title{
SERUM PREVALENCE TO NON-VIRAL PATHOGENS IN WILD FELIDS OF SOUTHERN PRIMORYE, RUSSIA
}

\author{
Sergey V. Naidenko ${ }^{1}$, Jose A. Hernandez-Blanco ${ }^{1}$, \\ Mariya N. Erofeeva ${ }^{1}$, Mikhail N. Litvinov ${ }^{2}$, Viatcheslav V. Rozhnov ${ }^{1}$ \\ ${ }^{1} A . N$. Severtsov Institute of Ecology and Evolution of RAS, Russia \\ e-mail: snaidenko@mail.ru,j.a.hernandez.blanco@gmail.com,erofeevamariya@yandex.ru,rozhnov.v@gmail.com \\ ${ }^{2}$ Federal Scientific Centre of the East Asia Terrestrial Biodiversity Eastern Branch of RAS, Russia \\ e-mail:mnlitvinov@rambler.ru
}

Received: 22.11.2018. Revised: 05.02.2019. Accepted: 10.02.2019.

\begin{abstract}
Serum prevalence to six different non-viral pathogens was estimated for big Russian cats (Amur tiger (Panthera tigris altaica) and the Far Eastern leopard (Panthera pardus orientalis)) in Southern Primorye, Russia $(\mathrm{n}=26)$ in 2008-2016. Serum samples from smaller cats (Eurasian lynx (Lynx lynx) and Far Eastern wildcat (Prionailurus bengalensis euptilurus $)$ ) were also tested for these pathogens $(\mathrm{n}=28)$ during the same period. Felids of Russian Southern Primorye showed serum prevalence to five out of six tested pathogens. Antibodies to Candida sp. and Trichinella sp. were found to be much more widespread in cats (47\% and $42 \%)$ than antibodies to other tested pathogens ( $20 \%$ and less). Large cats demonstrated a higher serum prevalence to these pathogens than smaller ones. We did not detect animals seropositive to Coxiella burnetii.
\end{abstract}

Key words: Amur tiger, Panthera tigris altaica, pathogens, Toxoplasma gondii, Trichinella

Infectious diseases may be a serious threat to wild animals that might result in population decline (Roelke-Parker et al., 1996; Murray et al., 1999; Deem et al., 2001). However, little is known about the presence of infectious pathogens in the populations of felids in the Russian Far East. Four wild cat species (Amur tiger (Panthera tigris altaica Temminck, 1844), Far Eastern leopard (Panthera pardus orientalis Schiegel, 1857), Eurasian lynx (Lynx lynx Linnaeus, 1758) and Far Eastern wildcat (Prionailurus bengalensis euptilurus Elliot, 1871)) inhabit the Russian Far East. The studies of seroprevalence in Amur tigers (Quigley et al., 2010; Goodrich et al., 2012a; Naidenko et al., 2018a) and in Far Eastern leopards (Goodrich et al., 2012b; Naidenko et al., 2018a) were conducted for some pathogens. There is only one study in comparative analysis of serum prevalence of four felid species to virus pathogens (Naidenko et al., 2018a). Some species-specific differences were found in serum prevalence to feline panleukopenia virus (FPV), canine distemper virus (CDV), feline calicivirus (FCV) and Aujezsky's disease (pseudorabies) virus. Serum prevalence to non-viral pathogens is poorly described for the carnivores of the Russian Far East. There is only one study on serum prevalence of bears (Ursus spp.) (Naidenko et al., 2018b). It described interspecific differences in serum prevalence to Toxoplasma gondii and Trichinella sp. There were no differences in serum prevalence of bear species to viral pathogens. Other studies showed that non-viral pathogens occur in small cats as well: $3 \%$ of the do- mestic cats (Felis catus Linnaeus, 1758) were serum positive to Mycoplasma sp. and Toxoplasma gondii, one Far Eastern wildcat was serum positive to Toxoplasma as well (Goncharuk et al., 2012).

We choose six non-viral pathogens for this study, which may be dangerous for different cat species. Some of them are very widespread: Toxoplasma, Trichinella, Mycoplasma, Chlamydia and Candida in mammals (including felids), Ig-G antibodies to Coxiella were found in domestic cats in the Russian Far East (Pavlova et al., 2016) and assumed to be present in wild cats as well. In this study, we estimated serum prevalence of four wild cat species to different non-viral pathogens in the Russian Far East. We analysed serum prevalence to six different pathogens: Toxoplasma gondii, Trichinella sp., Mycoplasma sp., Chlamydia sp., Candida sp., Coxiella burnetii. Toxoplasma gondii is the most widespread parasite in the world. Only cats may be definite hosts of these pathogens. However, Toxoplasma may parasitise in all vertebrates. Normally, Toxoplasma gondii results in abortion, brain problems and immunodeficiency on cats, but this infection may be fatal for the Pallas's cat (Otocolobus manul (Pallas, 1776)) (Ketz-Riley et al., 2003; Basso et al., 2005) and Sand cat (Felis margarita Loche, 1858) (Pas \& Dubey, 2008). Trichinella sp. is a nematode that inhabits the muscles of vertebrates (in mammals mainly the diaphragm and chewing muscles). This nematode may live and parasitise on almost all mammalian species (and on some avian species as well). But most commonly this para- 
site infects wild boars (Sus scrofa Linnaeus, 1758) (Kim et al., 2015), bears (Naidenko et al., 2013) and other carnivorous species (Gottstein et al., 2009). Mycoplasma sp. is a bacterial organism infecting many mammalian species, but usually not fatal for the host. Chlamydia sp. is another bacterial organism which transfers mainly during sexual contacts; it is dangerous for the pregnancy because it causes infection of the sexual tract (Sumithra et al., 2013). Candida sp. is a symbiotic fungal organism, which may be dangerous only due to co-infection or decrease of immunity (Edelmann et al., 2005). Coxiella burnetti is a bacterium that causes Q-fever, which may result in the death of the host (Arricau-Bouvery \& Rodolakis, 2005). Only Toxoplasma has been studied on felids in the Russian Far East. Other pathogens have never been considered for this group of animals in the wild so far.

Serum prevalence may show interspecific differences, which relates to host ecology and sensitivity to these pathogens (Pavlova et al., 2015, 2016). Three felid species (Amur tiger, Eurasian lynx and Far Eastern wildcat) inhabit the whole southern Primorye. The Far Eastern leopard inhabits only the Southwest of Primorye (National Park «Land of the Leopard»). Three large cats (including the lynx) prey mainly on ungulate species, like Nippon deer (Cervus nippon Temminck, 1838) and Siberian roe deer ( $\mathrm{Ca}$ preolus pygargus Pallas, 1771); tigers and leopards also hunt wild boars, and tigers prey on the Red deer as well (Cervus elaphus Linnaeus, 1758) (Kerley et al., 2015). All three cat species prey, too, on small carnivores (Pikunov \& Korkishko, 1992; Yudakov \& Nikolaev, 2012). Tigers may also prey on bears (Ursus arctos Linnaeus 1758, U. thibetanus G. [Baron] Cuvier, 1823) and occasionally they kill leopards and lynxes (Yudakov \& Nikolaev, 2012). Opposed to large cats, the Far Eastern wildcat mainly hunts rodents, amphibians and reptiles, and inhabits mixed forests with open meadows near streams and small ponds (Yudin, 2015). All species may come into contact with each other and domestic cats and dogs (tiger and Far Eastern wildcat come closer to the villages during winter, but feral cats and dogs are also seen regularly inside the forest). The aim of this study was to estimate inter-specific differences in serum prevalence to six non-viral pathogens in four wild felid species inhabiting the Southern Primorye.

\section{Material and Methods}

This study was conducted at the South of Primorsky Krai (Russia) in the Ussuriisky State Nature Reserve of the Russian Academy of Sciences (20082018) and in the National Park «The Land of Leop- ard» (2010-2018). The average altitude of this area is $300-400 \mathrm{~m}$ a.s.l. (rarely - up to $600 \mathrm{~m}$ a.s.1.). The study covered approximately $1500 \mathrm{~km}^{2}$. This area is characterised by low winter temperatures (average January temperature is $-17.9^{\circ} \mathrm{C}$ ) and warm summers (August temperature is $+19.7^{\circ} \mathrm{C}$ ) with high humidity levels $(70-80 \%)$. The objects of study were four species of Felidae: Amur tiger $(\mathrm{n}=18(11 \hat{\jmath}$, one of them 16-17 months old, and 7ㅇ), Far Eastern leopard $\left(n=8\left(4 \bigcirc^{\lambda}\right.\right.$ and 4 , , two of females $-1-1.5$ years old)), Eurasian lynx ( $\mathrm{n}=5$ (4仓 and $1 \circ, 1$ male and 1 female were 4-5 month old)), Far Eastern wildcat $(\mathrm{n}=23$ (18 $\hat{0}$ and 5 , , two females were 4-5 month old)). All animals were adults except the ones mentioned specifically. The details of capture and immobilisation procedures were described earlier (Rozhnov et al., 2013; Naidenko et al., 2018a) (Fig. 1). Six wildcats (out of 23) were studied in the Safari-Park (Primorsky Krai) where they spent up to six months in captivity before the study.

The blood samples were taken from the inguinal vein $(10-30 \mathrm{ml}$ in tigers and leopards, $1-3 \mathrm{ml}$ in smaller cats) (Fig. 2). Four serum samples (two leopards and two tigers) were obtained from wild animals that were transferred to captivity due to signs of disease, trauma or due to their behaviour (conflict tiger).

Blood samples were stored for $3-4$ hours $\left(+4^{\circ} \mathrm{C}\right)$ and then centrifuged for $20 \mathrm{~min}(2000 \times \mathrm{G})$. Aliquots of blood serum were placed in clear Eppendorf tubes and frozen under $-18^{\circ} \mathrm{C}$ until analyses (Naidenko et al., 2013). Serological reactions were done at A.N. Severtsov Institute of Ecology and Evolution of RAS. All serum samples were tested in the lab for the presence of antibodies to Toxoplasma gondii, Chlamydia sp., Mycoplasma sp., Candida sp., Trichinella sp. and Coxiella burnetii. If the amount of serum from some individuals was limited just few tests were conducted.

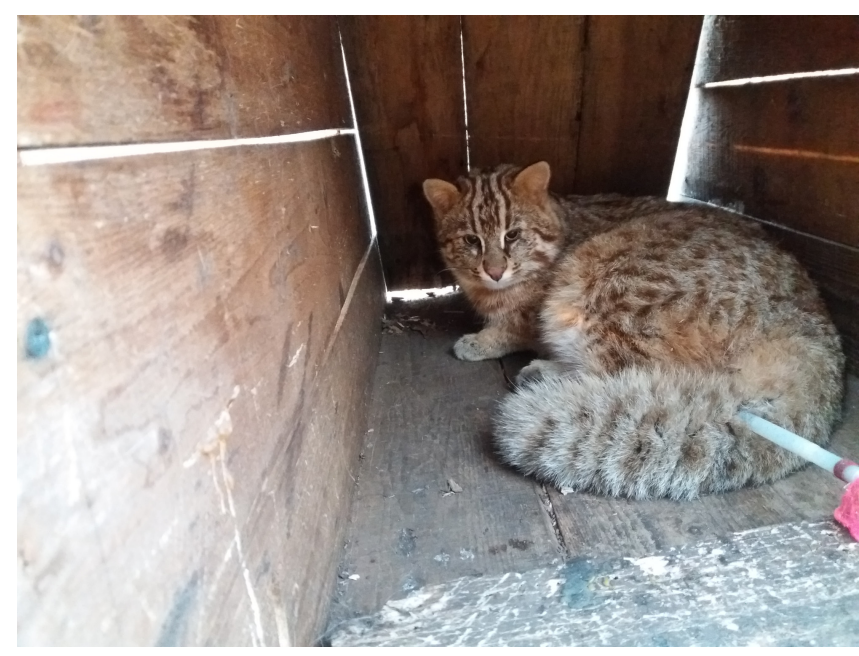

Fig. 1. Far Eastern wildcat captured in wooden trap after the injection of drugs. Photo: S.V. Naidenko. 


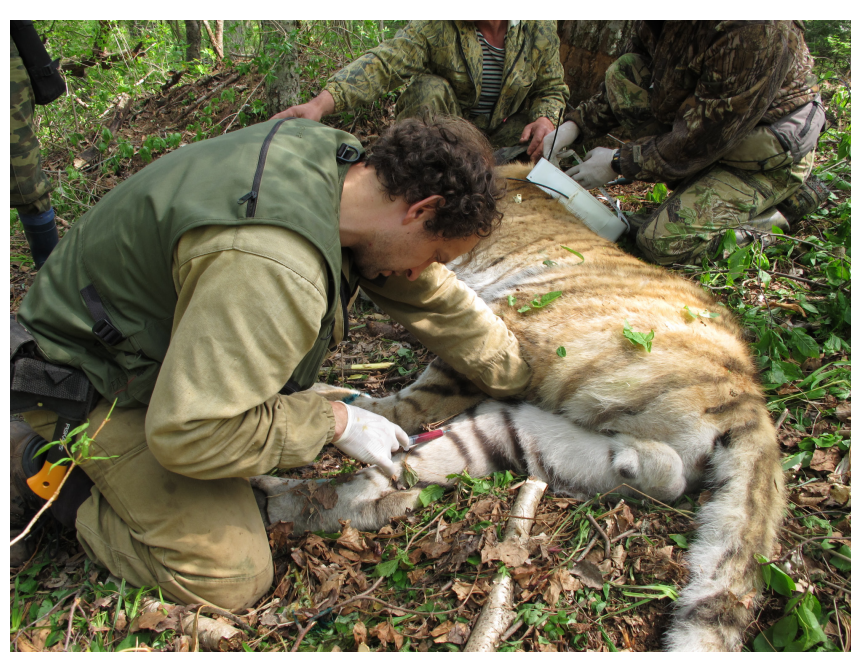

Fig. 2. Blood sampling in Amur tiger. Photo: N.V. Sidorchuk.

All tests for antibody presence of the first four mentioned pathogens were conducted with ELISA (Enzyme linked immune sorbent assay) (immobilised antigen placed on wells' bottom) using commercial kits (Chema, Moscow, Russia) (cut-off method). These kits were developed for carnivore species (with different cut-off level). The presence of the antibodies to Trichinella sp. and Coxiella burnetii was detected also by ELISA using commercial kits of IDVet (Grabels, France) (cut-off method). These kits were developed for a wide variety of mammalian species of several orders (including carnivores). All measurements were conducted accordingly to manufactures' protocols. It made the probability of false negative/positive results extremely low. However, we have to mention that the presence of antibodies to the pathogen (positive antibody test result) only indicates an exposure to pathogens and not necessarily a current infection.

A statistical analysis was conducted to compare the percentage of seropositive animals between species. The two-tailed Fisher's exact test was used. The $95 \%$ level of confidence was calculated and $p<0.05$ was considered to be statistically significant. Statistical analyses were conducted using Microsoft Excel (Microsoft Corporation, Redmond, Washington, USA) and Statistica version 8.0 (StatSoft, Inc., Tulsa, Oklahoma, USA).

\section{Results}

Six wildcats (out of 23) were studied in the Safari-Park (Primorsky Krai) where they spent up to six months in captivity before the study. We assume that they may be different to all cats captured and sampled immediately in the wild, because they had additional contacts with each other (they were housed in one enclosure) and some domestic animals (cats and dogs). We compared the serum prevalence of these cats to different pathogens with that of cats captured in the wild and combined the groups where we did not find any significant differences. In fact, significant differences were detected only in serum prevalence to Mycoplasma (Fisher's exact test: $p=0.005$ (five of six tested cats of the Safari-Park had antibodies to this pathogen)), so only wild-captured cats were included in the analysis below (for Mycoplasma sp.).

In the course of this study the antibodies to five of six tested non-viral pathogens were detected in felids in South Primorye (Table). There were no animals serum positive to Coxiella burnetii. Antibodies against five other pathogens were found in one to four feline species. Among all samples the serum prevalence of Candida and Trichinella was much higher than that of any other non-viral pathogen (respectively Fisher's exact test: $p=0.000$ 0.003 and $p=0.000-0.027$ ). The serum prevalence of Toxoplasma was also higher than of Chlamydia and Coxiella (Fisher's exact test: $\mathrm{p}=0.0026$ 0.0152 ). No other differences in serum prevalence to viruses were found among all cat samples.

Candida sp. is likely the most widespread (47\% serum positive tests) of the tested non-viral pathogens. All eight leopard samples were serum positive to Candida, as well as $50 \%$ of the tiger samples, $32 \%$ of the Far Eastern wildcats and one of the five lynxes. The antibodies to this pathogen were found significantly more often in leopards than in any other felid species (Fisher's exact test: $\mathrm{p}=0.0022-0.0233$ ). The serum prevalence to Candida did not differ between the other species.

Antibodies to Trichinella sp. were detected in $42 \%$ of the samples. The highest serum prevalence was found in the leopard (88\%) and tiger (72\%). This index was much lower for the Far Eastern wildcat $(10 \%)$ (respectively Fisher's exact test: $p=0.0002$ and $\mathrm{p}=0.0001)$. There were no lynxes serum positive to Trichinella (respectively for leopard and tiger Fisher's exact test: $\mathrm{p}=0.0047$ and $\mathrm{p}=0.0075$ ).

Table. Number of serum positive and tested (in brackets) felids to different pathogens

\begin{tabular}{|l|c|c|c|c|c|c|}
\hline Host species & Toxoplasma gondii & Trichinella sp. & Candida sp. & Mycoplasma sp. & Chlamydia sp. & Coxiella burnetii \\
\hline Tiger & $7(18)$ & $13(18)$ & $9(18)$ & $0(18)$ & $0(18)$ & $0(16)$ \\
\hline Leopard & $0(8)$ & $7(8)$ & $8(8)$ & $0(8)$ & $0(8)$ & $0(8)$ \\
\hline Lynx & $1(5)$ & $0(5)$ & $1(5)$ & $0(5)$ & $0(5)$ & $0(4)$ \\
\hline Wildcat & $3(23)$ & $2(21)$ & $7(22)$ & $2(17)$ & $2(22)$ & $0(8)$ \\
\hline
\end{tabular}


Twenty percent of the serum samples were seropositive to Toxoplasma gondii. The highest percentage of positive animals (39\%) was detected in tigers, compared to $20 \%$ for lynxes and $13 \%$ for Far Eastern wildcats. We did not find any leopard serum positive to Toxoplasma. However, statistical analysis did not find significant interspecific differences in serum prevalence to Toxoplasma.

Antibodies to Mycoplasma and Chlamydia were detected only in Far Eastern wildcats (respectively $4 \%$ and $4 \%$ of all tested felid samples or $12 \%$ and 9\% for wild-caught Far Eastern wildcats). We did not find any animal serum positive to these pathogens in other cat species. There were no significant species-specific differences in serum prevalence to Mycoplasma and Chlamydia in all four tested feline species.

\section{Discussion}

There are a lot of viral and non-viral pathogens (Naidenko et al., 2014, 2018a; Pavlova et al., 2015, 2016) that may be dangerous for wild felids. Dirofilaria sp., Cytauxzoon felis and other non-viral pathogens may be dangerous for wild cats in different regions (Zahedi et al., 1986; Ketz-Riley et al., 2003). However, here we chose five widespread non-viral pathogens and the sixth one (Coxiella), which was earlier noted for the domestic cats in the Russian Far East (Pavlova et al., 2016). We detected the presence of five non-viral pathogens in felines in South Primorye. We did not find animals that were seropositive to Coxiella burnetii among the four wild felids. An earlier study (Naidenko et al., 2018b) did not find antibodies to this pathogen in bears in the Russian Far East either. It seems that this pathogen is extremely rare in Carnivores of the Russian Far East.

Among other pathogens, Candida was the most widespread, although this Fungus is only dangerous when the animal's immunity is low. It is notable that the most genetically monomorphic species (Uphyrkina et al., 2001) - the Far Eastern leopard - had the highest serum prevalence to this pathogen among all cats. The Amur tiger (a subspecies with a low genetic diversity (Luo et al., 2004)) also showed high a serum prevalence to Candida. Low genetic diversity may be related to the decrease of an animal's immunity (Lucash et al., 2017) and, possibly, increases the susceptibility to different pathogens. Although, the effect of genetic diversity on serum prevalence to Candida is unclear yet, large cats had a higher index of it than the smaller ones. This pathogen also occurs in bears in the Russian Far East - more than 50\% were serum positive to Candida (Naidenko et al., 2018b).
Trichinella is a very widespread nematode that infects many vertebrates. It may result to the death of experimental animals (Zaiman et al., 1960; Kozar \& Kozar, 1965) and of humans (Sethi et al., 2012). But the mortality of mammals has not been described in the wild. Among mammals, the «traditional» hosts for this pathogen are wild boars (Kim et al., 2015), bears (Naidenko et al., 2013) and other Carnivores (Gottstein et al., 2009). In Southern Primorye large cats had a higher prevalence to this pathogen than smaller ones, which may be related to their diet. The Amur tiger preys mainly on wild boar (one of the main carriers of Trichinella) and other large ungulates (Red deer and Nippon deer (Kerley et al., 2015)). The Far Eastern leopard also preys on ungulates, while the wild boar is quite rare on its diet. However, small carnivores, mainly the Asian badger (Meles leucurus (Hodgson, 1847)) and Raccoon dog (Nyctereutes procyonoides (Gray, 1834)) are killed by leopards quite often (Pikunov \& Korkishko, 1992). These diet traits may explain the high level of serum prevalence to Trichinella of tiger and leopard. However, lynxes and Far Eastern wildcat do not prey on wild boar, badger and raccoon dog. Lynxes hunt mainly small and medium-sized ungulates (Roe deer and Nippon deer). Wildcats hunt predominantly rodents, birds and amphibians. The percentage of serum positive animals among the prey of these cats was presumably much lower than in the prey of large cats.

Toxoplasma gondii is the most widespread parasite over the world and may infect all warm-blooded animals. Felids are a definite host of this pathogen and show a high serum prevalence to it in the wild (Penzhorn et al., 2002; Simon et al., 2013), excluding Pallas' cat (Naidenko et al., 2014), which is extremely susceptible to this pathogen (Ketz-Riley et al., 2003). Most likely, its lethality in the wild as well as environmental conditions restrict the distribution of this pathogen in Pallas' cat habitats (Pavlova et al., 2015, 2016). In the Russian Far East we did not find significant interspecific differences in serum prevalence to Toxoplasma between the studied cat species. It was slightly higher in tigers than in other cat species. We did not find antibodies to this pathogen in leopards, although earlier studies found serum positive leopards in this region (Goodrich et al., 2012b). It seems that this pathogen occurs in this region quite often (see also Naidenko et al., 2018b, and this study), at least much more often than in dry areas (Naidenko et al., 2014; Pavlova et al., 2016).

Mycoplasma and Chlamydia were found only in Far Eastern wildcats, and the level of serum 
prevalence was low. These pathogens have never been described earlier in tigers and leopards, not having ever been studied in large cats before. An earlier study found an animal serum positive to $M y$ coplasma among domestic cats (Goncharuk et al., 2012). These pathogens were also found in bears in the Russian Far East (Naidenko et al., 2018b). They do not have a lethal effect but may influence the animal's body condition. Based on the low percentage of serum positive animals we assumed that these pathogens may occur in all felids' species.

\section{Conclusions}

We found significant inter-species differences in felids serum prevalence to different pathogens. The serum prevalence to non-viral pathogens was higher in large cats than in smaller ones, significantly for Candida (only leopards) and Trichinella. It may be partly related with the diet of cats (tigers and leopards hunting wild boars - probable source of Trichinella sp.). The main source of Candida for leopards is unclear. We may assume that high serum prevalence of the Far Eastern leopard may be related to a low genetic diversity of this subspecies (Uphyrkina et al., 2001). It may decrease the immunity and increase susceptibility of leopards to this pathogen. The serum prevalence to non-viral pathogens differed of viral pathogen patterns where there were no significant differences in serum prevalence between large and smaller cats (excluding FPV, which seems lethal for the lynxes (Naidenko, 2005; Naidenko et al., 2018a)). So far, antibodies to Mycoplasma and Chlamydia were found only in Far Eastern wildcat opposed to other cats. Probably, these pathogens are very common in domestic and stray dogs and $\mathrm{Myco}$ plasma antibodies were also found in domestic cats (Goncharuk et al., 2012). Far Eastern wildcats visit villages in winter time, which may be a way of infection. Five of the six wildcats in the Safari Park got the antibodies to Mycoplas$m a$ half a year after capturing. Further studies of felid diseases in the Russian Far East should consider the main ways of transmission of the pathogens and their vectors.

\section{Acknowledgements}

The authors express their gratitude to E. Shevtsova and E. Blidchenko (National Park «Land of the Leopard»), who provided two blood samples from leopards. This study was supported by the Russian Science Foundation №14-18-00200 (Far Eastern wildcats and lynxes) and Russian Geographical Society (Amur tiger and Far Eastern leopard project).

\section{References}

Arricau-Bouvery N., Rodolakis A. 2005. Is Q fever an emerging or re-emerging zoonosis? Veterinary Research 36(3): 327-349. DOI: 10.1051/vetres:2005010

Basso W., Edelhoffer R., Zenker W., Mostl K., Kubber-Heiss A., Prosl H. 2005. Toxoplasmosis in Pallas' cats (Otocolobus manul) raised in captivity. Parasitology 130(3): 293-299. DOI: 10.1017/S0031182004006584

Deem S.L., Karesh W.B., Weisman W. 2001. Putting theory into practice: wildlife health in conservation. Conservation Biology 15(5): 1224-1233. DOI: 10.1111/j.1523-1739.2001.00336.x

Edelmann A., Krüger M., Schmid J. 2005. Genetic relationship between human and animal isolates of Candida albicans. Journal of Clinical Microbiology 43(12): 6164-6166. DOI: 10.1128/JCM.43.12.6164-6166.2005

Goncharuk M., Kerley L., Naidenko S., Rozhnov V. 2012. Prevalence of seropositivity to pathogens in small carnivores in adjacent areas of Lazovskii Reserve. Biology Bulletin 39(8): 708-713. DOI: 10.1134/ S1062359012080067

Goodrich J.M., Quigley K.S., Lewis J.C., Astafiev A.A., Slabi E.V., Miquelle D.G., Smirnov E.N., Kerley L.L, Armstrong D.L., Quigley H.B. 2012a. Serosurvey of free-ranging Amur tigers in the Russian Far East. Journal of Wildlife Diseases 48(1): 186-189. DOI: 10.7589/0090-3558-48.1.186

Goodrich J.M., Lewis J.C.M., Quigley K.S., Roelke M., Astafiev A.A., Slabii E.V., Miquelle D.G., Smirnov E.N., Kerley L.L., Armstrong D.L., Seryodkin I.V., Quigley H.B., Hornocker M.G. 2012b. Infection diseases of Amur tigers and Far Eastern leopards. In: I.V. Seryodkin, D.G. Miquelle (Eds.): Diseases and parasites of wildlife in Siberia and the Russian Far East. Vladivostok: Dalnauka. P. 19-26. [In Russian]

Gottstein B., Pozio E., Nockler K. 2009. Epidemiology, diagnosis, treatment, and control of Trichinellosis. Clinical Microbiological Reviews 22(1): 127-145. DOI: 10.1128/CMR.00026-08

Kerley L.L., Mukhacheva A.S., Matyukhina D.S., Salmanova E., Salkina G.P., Miquelle D.G. 2015. A comparison of food habits and prey preference of Amur tiger (Panthera tigris altaica) at three sites in the Russian Far East. Integrative Zoology 10(4): 354-364. DOI: 10.1111/1749-4877.12135

Ketz-Riley C.J., Ritchey J.W., Hoover J.P., Johnson C.M., Barrie M.T. 2003. Immunodeficiency associated with multiple concurrent infections in captive Pallas' cats (Otocolobus manul). Journal of Zoo Wildlife Medicine 34(3): 239-245. DOI: 10.1638/01-112

Kim H.J., Jeong W.S., Kim E.M., Yeo S.G., An D.J., Yoon H., Kim E.J., Park C.K. 2015. Prevalence of Trichinella spp. antibodies in wild boars (Sus scrofa) and domestic pigs in Korea. Veterinarni Medicina 60(4): 181-185. DOI: 10.17221/8105-VETMED 
Kozar Z., Kozar M. 1965. A comparison of infectivity and pathogenicity of Trichinella spiralis strains from Poland and Kenya. Journal of Helminthology 39(1): 19-34. DOI: $10.1017 / \mathrm{S} 0022149 X 00020058$

Lucash B., Westerdahl H., Strandh M., Winkler H., Moodley Y., Knauer F., Hoi H. 2017. Genes of the major histocompatibility complex highlight interactions of the innate and adaptive immune system. PeerJ 5: e3679. DOI: $10.7717 /$ peerj.3679

Luo S.J., Kim J.H., Johnson W.E., van der Walt J., Martenson J., Yuhki N., Miquelle D.G., Uphyrkina O., Goodrich J.M., Quigley H.B., Tilson R., Brady G., Martelli P., Subramaniam V., McDougal C., Hean S., Huang S.Q., Pan W., Karanth U.K., Sunquist M., Smith J.L.D., O'Brien S.J. 2004. Phylogeography and genetic ancestry of tigers (Panthera tigris). PLoS Biology 2: e442.

Murray D.L., Kapke C.A., Evermann J.F., Fuller T.K. 1999. Infectious disease and the conservation of free-ranging large carnivores. Animal Conservation 2(4): 241-254. DOI: $10.1017 / \mathrm{S} 1367943099000578$

Naidenko S.V. 2005. Traits of reproduction and postnatal development of Eurasian lynx. Moscow: KMK Scientific Press Ltd. 112 p. [In Russian]

Naidenko S.V., Ivanov E.A., Mordvintsev I.N., Platonov N.G., Ershov R.V., Rozhnov V.V. 2013. Seropositivity for different pathogens in polar bears (Ursus maritimus) from Barents Sea Islands. Biology Bulletin 40(9): 779782. DOI: $10.1134 / \mathrm{S} 1062359013090082$

Naidenko S.V., Pavlova E.V., Kirilyuk V.E. 2014. Detection of seasonal weight loss and a serologic survey of potential pathogens in wild Pallas' cats (Felis [Otocolobus] manul) of the Daurian steppe, Russia. Journal of Wildlife Diseases 50(2): 188-194. DOI: 10.7589/2013-03-068

Naidenko S.V., Hernandez-Blanco J.A., Pavlova E.V., Erofeeva M.N., Sorokin P.A., Litvinov M.N., Kotlyar A.K., Sulikhan N.S., Rozhnov V.V. 2018a. Primary study of seroprevalence to virus pathogens in wild felids of South Primorie, Russia. Canadian Journal of Zoology 96(8): 839-846. DOI: 10.1139/cjz-2017-0192

Naidenko S.V., Hernandez-Blanco J.A., Seryodkin I.V., Miquelle D.G., Blidchenko E.Yu., Litvinov M.N., Kotlyar A.K., Litvinov M.N., Kotlyar A.K. 2018b. Serum prevalence of the bears in the Russian Far East to different pathogens. Zoologicheskii Zhurnal 97(9): 1189-1194. [In Russian]

Pas A., Dubey J.P. 2008. Fatal toxoplasmosis in sand cats (Felis margarita). Journal of Zoo and Wildlife Medicine 39(3): 362-369. DOI: 10.1638/2007-0149.1

Pavlova E.V., Kirilyuk V.E., Naidenko S.V. 2015. Patterns of seroprevalence of feline viruses among domestic cats (Felis catus) and Pallas' cats (Otocolobus manul) in Daursky Reserve, Russia. Canadian Journal of Zoology 93(11): 849-855. DOI: 10.1139/cjz-2015-0006

Pavlova E.V., Kirilyuk V.E., Naidenko S.V. 2016. Occurrence pattern of influenza A virus, Coxiella burnetii, Toxoplasma gondii, and Trichinella sp. in the Pallas cat and domestic cat and their potential prey under arid climate conditions. Arid Ecosystems 6(4): 277-283. DOI: $10.1134 /$ S2079096116040089

Pikunov D.G., Korkishko V.G. 1992. Leopard of the Russian Far East. Moscow: Nauka. 191 p. [In Russian]

Penzhorn B., Stylianides E., van Vuuren M., Alexander K., Meltzer D.G.A., Mukarati N.L. 2002. Seroprevalence of Toxoplasma gondii in free-ranging lion and leopard populations in Southern Africa. African Journal of Wildlife Research 32(2): 163-165.

Quigley K.S., Evermann J.F., Leathers C.W., Armstrong D.L., Goodrich J., Duncan N.M., Miquelle D.G. 2010. Morbillivirus infection in a wild Siberian tiger in the Russian Far East. Journal of Wildlife Diseases 46(4): 1252-1256. DOI: 10.7589/0090-3558-46.4.1252

Roelke-Parker M.E., Munson L., Packer C., Kock R., Cleaveland S., Carpenter M., O’Brien S.J., Pospischil A., Hofmann-Lehmann R., Lutz H. 1996. A canine distemper virus epidemic in Serengeti lions (Panthera leo). $\mathrm{Na}$ ture 379(6564): 441-445. DOI: 10.1038/379441a0

Rozhnov V.V., Hernandez-Blanko J.A., Lukarevskii V.S., Naidenko S.V., Sorokin P.A., Litvinov M.N., Kotlyar A.K., Pavlov D.S. 2013. Application of satellite collars to the study of home range and activity of the Amur tiger (Panthera tigris altaica). Biology Bulletin 38(8): 834-847. DOI: 10.1134/S1062359011080073

Sethi B., Butola K.S., Kumar Y., Mishra J.P. 2012. Multiple outbreaks of trichinellosis with high mortality rate. Tropical Doctor 42(4): 243. DOI: 10.1258/ td.2012.110335

Simon A., Poulin M.G., Rousseau A.U., Dubey J.P., Ogden N.H. 2013. Spatiotemporal dynamic of Toxoplasma gondii infection in Canadian lynx (Lynx canadensis) in western Quebec, Canada. Journal of Wildlife Diseases 49(1): 39-48. DOI: 10.7589/2012-02-048

Sumithra T.G., Chaturvedi V.K., Susan C., Siju S., Rai A.K., Harish C., Sunita S. 2013. Mycoplasmosis in wildlife: a review. European Journal of Wildlife Research 59(6): 769-781. DOI: 10.1007/s10344-013-0769-9

Uphyrkina O., Johnson W.E., Quigley H., Miquelle D., Marker L., Bush M., O’Brien S.J. 2001. Phylogenetics, genome diversity and origin of modern leopard, Panthera pardus. Molecular Ecology 10(11): 2617 2633. DOI: 10.1046/j.0962-1083.2001.01350.x

Yudakov A.G., Nikolaev I.G. 2012. Winter ecology of the Amur tiger. Vladivostok: Dalnauka. 199 p.

Yudin V.G. 2015. Far Eastern Wildcat. Vladivostok: Dalnauka. 442 p. [In Russian]

Zaiman H., Hecht H.S., Howard R.G. 1960. Mortality of young male mice infected with 6,400 normal or irradiated Trichinella spiralis larvae. Experimental Parasitology 10(3): 284-286. DOI: 10.1016/0014-4894(60)90066-7

Zahedi M., Vellayan S., Jeffery J., Krishnasamy M. 1986. A case of double infection with Brugia pahangi and Dirofilaria immitis in a Malaysian clouded leopard, Neofilis nebulosi. Veterinarian Parasitology 21(2): 135-137. DOI: 10.1016/0304-4017(86)90154-8 


\title{
СЕРОПОЗИТИВНОТЬ К НЕВИРУСНЫМ ПАТОГЕНАМ ДИКИХ КОШАЧЬИХ ЮГА ПРИМОРСКОГО КРАЯ
}

\author{
С. В. Найденко ${ }^{1}$, Х. А. Эрнандес-Бланко ${ }^{1}$, М. Н. Ерофеева ${ }^{1}$, М. Н. Литвинов ${ }^{2}$ В. В. Рожнов ${ }^{1}$ \\ ${ }^{1}$ Институт проблем экологии и эволюиии имени А.Н. Севериова РАН, Россия \\ e-mail:snaidenko@mail.ru,j.a.hernandez.blanco@gmail.com,erofeevamariya@yandex.ru,rozhnov.v@gmail.com

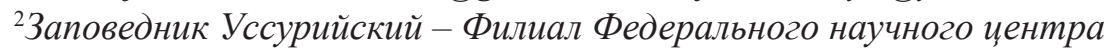 \\ биоразнообразия наземной биоть Восточной Азии ДВО РАН, Россия \\ e-mail:mnlitvinov@rambler.ru
}

\begin{abstract}
Серопозитивность к шести различным невирусным патогенам была оценена для двух крупных кошачьих юга Приморского края - амурского тигра (Panthera tigris altaica) и дальневосточного леопарда (Panthera pardus orientalis) $(\mathrm{n}=26)$ в 2008-2016 гг. Образцы сывороток мелких кошачьих (евразийской рыси (Lynx lynx) и дальневосточного лесного кота (Prionailurus bengalensis euptilurus)) также были проанализированы на антитела к этим патогенам $(\mathrm{n}=28)$ в этот же период времени. У кошачьих южного Приморья России выявили серопозитивность к пяти из шести проанализированных патогенов. Наиболее часто у кошачьих выявляли антитела к Candida sp. и Trichinella sp. (соответственно у 47\% и 42\% животных). А антитела к другим патогенам отмечали менее чем у 20\% животных. Среди крупных кошачьих отмечали большую долю серопозитивных животных к этим патогенам, чем среди мелких кошек. Мы не выявили животных серопозитивных к Coxiella burnetii.
\end{abstract}

Ключевые слова: Panthera tigris altaica, Toxoplasma gondii, Trichinella, амурский тигр, патогены 